\title{
Study on the Issues of the Integration of Computer and Networks into College English Teaching
}

\author{
Honggai Cai ${ }^{1, a}$ \\ ${ }^{1}$ North China Electric Power University, Yonghuabei Street, \\ Beishi District, \\ Baoding, Hebei, China, 071000 \\ acaihgai79@sina.com
}

\begin{abstract}
The paper summarizes the current college English teaching mode researches and practices, that is the integration of computer and networks into college English teaching, in the wake of Ministry of Education issuing college English curriculum, which proposes computer \& network and classroom based English teaching mode in 2004. Computer and network, as the most important part of information technology, is the carrier of information, which can provide abundant interesting, vivid, interactive, humanistic, and learning materials for foreign language learners. The thesis aims to comb the related problems of integration and address the college English teaching under the background of computer and network. Based on the author's teaching experience, it aims to add some ideas into the study on the roles of computer and network in foreign language teaching and learning.
\end{abstract}

Keywords-computer and networks integration college English teaching

\section{INTRODUCTION}

Since the 1990s, computer and networks has been developing rapidly, which have greatly changed a lot of works in many fields, especially foreign language learning and teaching. It is ten years since the ministry of education issued college English curriculum proposing computer \& network and classroom based English teaching mode in 2004. Since then computer and network is regarded as an indispensable part of foreign language teaching. It also has begun the process of integrating computer and network to college English learning and teaching. The universities and colleges across the whole country have followed the policy and began to conduct a series of college English teaching reform and established the learner autonomous center which combines the traditional classroom and cyber based learning environment. This mode of foreign language learning and teaching has achieved great success in enriching teaching and learning materials, appealing to students and cultivating students' autonomous learning in the last ten years. But after ten years, this mode of learning and teaching give rise to a great variety of problems. All in all, the students overall English application ability can not meet the needs of the development of themselves and society. So there is a growing call for the next round of the foreign language learning and teaching reform in

\author{
Zhe $\mathrm{Guo}^{2}$ \\ ${ }^{2}$ North China Electric Power University, Yonghuabei Street, \\ Beishi District, \\ Baoding, Hebei, China, 071000
}

universities and colleges and even in society.

\section{II.LITERATURE REVIEW}

\section{A. Previous Studies on CALL \&MCALL}

CALL is for computer assisted language learning. Since the 1990s, computer and networks has been developing rapidly, which have greatly changed a lot of works in many fields. Nowadays the studies of CALL focus on the concrete teaching problems such as computers functioning in language teaching, online writing, online reading, multimedia applications, especially cyber-based autonomous learning, the integration of computer and networks into college English teaching. MCALL stands for multimedia computer assisted language teaching. The most striking feature of MCALL is still based on visual and auditory cognition.

The study of CALL even MCALL have gone to a high stage, especially in our country after 2004. Numerous studies mushroom across the whole country in response to the reform of ministry of education. Study on Leaner Autonomy of English Majors in Web - based Environment, Liu Jin xia (2009); on the characteristics of multimedia computer assisted language learning Yang Chuihui(2000) list five characteristics of MCALL and student-centered teaching mode; Zhang Xiaoying \&Li Tian xian's constructivism and Multimedia-assisted college English teaching. Xiao Haozhang, Wang Limei compares and comments on the five college teaching models (2007) and finds out their respective advantages and analyzes their existing problems, especially they point out the striking benefits of foreign teaching mode.

\section{B. theoretical backgrounds}

Founded by Jean Piaget, constructivism argues that humans generate knowledge and meaning from an interaction between their experiences and their ideas. It means that individuals construct new knowledge from their experiences by incorporating new experience into an already existing framework without changing that framework. When it comes to the college English learning it think students are active learners instead of passive receivers but they help students to construct their own knowledge system rather than just transfer knowledge to them. 


\section{COMPUTER \& NETWORK AND COLLEGE ENGLISH TEACHING}

Since the 1990s, computer and networks has been developing rapidly, which have greatly changed a lot of works in many fields, especially foreign language learning and teaching. Computer and network, as the most important part of information technology, is the carrier of information, which can provide abundant interesting, vivid, interactive, humanistic, and learning materials for foreign language learners. The main feature of information technology is sensing technology. Information carrier takes a great of variety of forms: images, sounds and texts. First it has changed the traditional way of information transmission and acceptance besides it has also changed the teaching content and teaching activities. It has turned foreign language teaching "textbook, blackboard, chalk and teacher monologue" into "PPT, computer, network" informationized style. Tolboom (2003) think that the construction of foreign language learner autonomous learning is the integrality of hardware, software and educational activities. $\mathrm{t}$ has drastic effect on the construction of foreign language learner's cyber based learning environment. The leading role of information technology in college English learning and teaching is optimizing the foreign language teaching such as teaching materials.

\section{TWO MAJOR OF BENEFITS OF MCALL}

This mode of foreign language learning and teaching has achieved great success in enriching teaching and learning materials, appealing to students and cultivating students' autonomous learning in the last ten years. First it has changed the traditional way of information transmission and acceptance besides it has also changed the teaching content and teaching activities. With the computer integration into foreign language teaching, it has changed the curriculum design, teaching mode. Student-centered teaching has challenged teacher -centered teaching. Computer is not just an assistant and becomes an integrate part of foreign language teaching and learning. It has most two important benefits compared with the traditional classroom teaching.

\section{A. Information Rich Environment}

The new way of classroom has provides an information-rich environment that enhances students' linguistic and cultural knowledge. Language learning is different from other science subjects, such as math, physics...which more depend on learners' critical and logical thinking, that is the depth of thinking however, language learning relies on the real rich input of language materials. Computer and network, as the most important part of information technology, is the carrier of information, which can provide abundant interesting, vivid, interactive, humanistic, and learning materials for foreign language learners as well as free from time and place restriction.

\section{B. The autonomous learning center}

With the computer and network into college English teaching, it highlights the individual and autonomous learning, which can be seen as the most obvious outcome of computer and network's integration into traditional classroom. It has been found that the use of computers has a greater equality between students and teachers than in traditional classrooms, decentralizing teacher authority (e.g. Kern 1995). In traditional classrooms, teachers work as the leader of the classroom, most time giving knowledge whereas students act as passive receiver of knowledge. Teacher's power and suppression can be observed clearly in traditional classrooms. Traditional classroom teaching features by hierarchical relationships, students are used to passive learners with teachers' centered role. However the roles teachers play in the new classrooms are organizer/manager or facilitator (Mark, 1995). As the teachers let go, students gained authority and confidence to step forward to initiate discussions and supplements teachers' replies.

\section{V.THE Related Issues After Ten YeARs’ APPLiCATION OF MCALL}

The new teaching mode has turned foreign language teaching "textbook, blackboard, chalk and teacher monologue" into "PPT, computer, network" informationized style. It has drastic effect on the construction of foreign language learner's cyber based learning environment. But after ten years, this mode of learning and teaching give rise to a great variety of problems: firstly, the students' listening level has been improved but speaking still lags behind; secondly the students' language competence has not improved much compared with what they have got in high school; thirdly the students can't take English as an tool to catch the latest development of their major knowledge and they lack critical thinking to judge and evaluate the materials English learners must become functionally literate, able to speak, understand read and write English and as well as use English to acquire and expand their knowledge to deepen their awareness of English as an international language.; fourthly the international published paper of our college students is still at low stage in the whole world, even compared with the major Asian countries, such as Japan, Korea, Taiwan. All in all, the students overall English application ability can not meet the needs of the development of themselves and society.

\section{A. Overloaded Information.}

Multimedia frees the teachers from writing words and sentences on blackboard. On the one hand, it saves teachers' time on the other hand it results in the flood of information. Learners don't have enough time to encode and decode excessive information. Learners work as just audience, teachers as projectors. As the saying goes "where there is multimedia, there is class." When something wrong with the multimedia, there is no class.

After class when students start their own autonomous learning in multimedia room, some will waste time choosing valuable information for them. They can not 
distinguish between valuable and invaluable ones. In addition, if students' self control is low, most of time he is distracted by the overloaded information online.

\section{B. Interpersonal Communications}

This type of teaching lacks interpersonal communication between teacher and students and also between learners. Learners just watch the computer screen, just like watching a film passively. English, as one of world languages, is for people to Face to face communicate with each other which are the complex combination of voice, facial expression, eye contact and body language.

This way of English teaching leads to the decrease in students' enthusiasm, initiative and creativity in English learning since it treats English as a kind of knowledge instead of a tool for communication. The new mode of teaching challenges students to be mature learners with high self-control and learning abilities. In a web based CALL context some feel confused and disoriented.

\section{Teachers' and Students' Low Computing Expertise}

To develop a high quality multimedia ppt is not easy for an individual English teacher, because it requires three fields' knowledge: competence in the target subject area, pedagogical skills and computing expertise. For most English teachers, their computer knowledge is just at primary stage.

\section{CONCLUSIONS}

Computer and networks, convenient and intelligent, has been the important tool for people to entertain, communicate, and learn. With technology developing, foreign language teaching is not "textbook, blackboard, chalk and teacher monologue" but "PPT, computer, network" informationized style. Although this teaching model can arouse students' interest in learning English and help students learn the language effectively and efficiently. This mode of teaching has achieved a great success but it doesn't change college English teaching "high input \&low output”, give rise to a great variety of potential problems. All in all, the students overall English application ability can not meet the needs of the development of themselves and society. So there is a growing call for the next round of the foreign language learning and teaching reform in universities and colleges and even in society.

\section{REFERENCE}

[1] Blake, Robert J. New Trends in Using Technology in the Language Curriculum [J]. Annual Review of Applied Linguistics, 27, pp7 6-9 7.2007.

[2] Debski, Robert. Analysis of research in CALL (1980-2000) with a reflection on CALL as an academic discipline [J] recall, (15).2003.

[3] Levy, Mike. Francoise B. \& Claire, B. S. World CALL: international perspectives on computer-assisted language learning [M].Taylor \&Francis. 2010.

[4] Jia Guodong Computer Assisted Language Teaching-theory and practice, Beijing: Higher Education press, 2007.

[5] Tan Yanling Computer Assisted Language Teaching Among 10 Years: reflection [J] Foreign Language electronic Teaching, 2007(5)

[6] Xiao Haozhang,Wang Limei College English Teaching Model Reform, foreign language and foreign language teaching,2007(2)

[7] Zhang Xiaoying,Li Tianxian constructivism and Computer Assisted Language Teaching [J] Foreign Language electronic Teaching,2002(2) 